\title{
Efektivitas Remediasi Kognitif terhadap Perbaikan Fungsi Kognitif pada Penderita Skizofrenia Rawat Inap di Rumah Sakit Jiwa A di Yogyakarta
}

\author{
Weni Susilo Rini ${ }^{1} \mathcal{E}$ M. Noor Rochman Hadjam ${ }^{2}$ \\ Fakultas Psikologi Universitas Gadjah Mada
}

\begin{abstract}
The aim of this reasearch to evaluate the effectiveness of cognitive remediation therapy in improving cognitive function of schizophrenia inpatient. This research was a quasi experimental with untreated control group design with dependent pretest and posttest. Fourteen schizophrenic inpatients were assigned to either a cognitive remediation group $(n=7)$ or a control group $(n=7)$. Cognitive dysfunctions were assessed using validated Indonesian version of Cognitive Assessment Interview (CAI). The intervention consisted of 12 sessions in 3 weeks, and was conducted in groups. Result Cognitive training group showed significant improvements in attention(effect size 0.65), working memory (effect size 0.68) and processing speed (effect size 0.61)after the intervention compared to the control group, but no significant improvement in global cognitive function. Conclusion the research suggests that cognitive remediation is not effective to improve global cognitive function and effective to improve attention, working memory and processing speed in hospitalized schizophrenic patients.
\end{abstract}

Keywords: cognitive, cognitive remediation, schizophrenia

\begin{abstract}
Abstrak. Tujuan penelitian ini adalah untuk menilai efektivitas terapi remediasi kognitif dalam meningkatkan fungsi kognitif pada penderita skizofrenia rawat inap. Penelitian ini merupakan eksperimen kuasi dengan desain untreated control group design with dependent pretest and posttest. Penderita skizofrenia sebanyak 14 orang dibagi ke dalam kelompok eksperimen ( $\mathrm{N}=7$ ) dan kontrol ( $\mathrm{N}=7$ ). Fungsi kognitif dinilai dengan Cognitive Assessment Interview (CAI) versi Indonesia yang telah divalidasi. Intervensi dilakukan dalam 12 kali pertemuan dalam waktu 3 minggu dan dilakukan dalam kelompok. Fungsi kognitif global tidak menunjukkan perbedaan yang signifikan antara kelompok ekperimen dan kelompok kontrol. Kelompok eksperimen menunjukkan perbaikan yang bermakna pada ranah atensi (effect size 0,65), memori kerja (effect size 0,68) dan kecepatan pemrosesan (effect size 0,61). Kesimpulan dari penelitian ini adalah remediasi kognitif tidak efektif memperbaiki fungsi kognitif global dan efektif dalam memperbaiki fungsi atensi, memori dan kecepatan pemrosesan pada penderita skizofrenia rawat inap.
\end{abstract}

Kata kunci : kognitif, remediasi kognitif, skizofrenia

Skizofrenia terjadi di seluruh dunia dengan angka kejadian 15,2 per 100.000 penduduk dan risiko morbiditas seumur

${ }^{1}$ Korespondensi mengenai isi artikel ini dapat dilakukan melalui : wenisusilorini@mail.ugm.ac.id

2 Atau melalui nrochman@ugm.ac.id hidup sebesar 7,2 per 1000 penduduk (McGrath, Saha, Chant \& Welham, 2008). Di Indonesia Riset Kesehatan dasar tahun 2013 menemukan fakta bahwa 1,7 per mil atau 1-2 orang dari 1000 orang mengalami gangguan jiwa berat, 
termasuk skizofrenia. Gangguan jiwa berat terbanyak terjadi di Aceh dan Yogyakarta yaitu sebesar 2,7 per mil (Kemenkes RI, 2013). Prevalensi seumur hidup skizofrenia rata-rata mencapai 0,3-0,7\% meskipun angka tersebut bervariasi berdasarkan etnis, negara dan geografis (APA, 2013).

Skizofrenia menyebabkan beban ekonomi yang besar bagi penderita dan keluarganya. Beban ekonomi tersebut salah satunya disebabkan oleh menurunnya produktivitas akibat disabilitas (Chong et al., 2011). Disabilitas pada skizofrenia terutama disebabkan oleh gangguan kognitif, disamping faktor faktor lain yaitu keadaan lingkungan (kesempatan, dukungan sosial, stigma, kemiskinan), status kesehatan, kapasitas fungsi, kebugaran fisik dan gejala depresi (Harvey \& Strassnig, 2012). Aspek kognitif ini sangat berperan dalam menentukan outcome fungsi penderita dibandingkan gejala skizofrenia. Kemampuan kognitif memegang peran penting terhadap fungsi penderita skizofrenia dalam segala aspek kehidupan. Gangguan fungsi kognitif pada skizofrenia berhubungan dengan outcome fungsional yaitu hambatan fungsi penderita di masyarakat, kesulitan dalam memecahkan masalah, penurunan keberhasilan dalam program rehabilitasi dan ketidakmampuan mempertahankan pekerjaan (Keefe \& Fenton, 2007).

Skizofrenia memiliki gambaran penurunan kognitif yang relatif stabil dan persisten sepanjang perjalanan penyakitnya. Pada penderita skizofrenia fase stabil defisit ini masih ada (Barder., Sundet., Rund., Evensen., Haahr., Hegelstad., \& Friis, 2013). Penurunan kognitif merupakan inti dari skizofrenia, meskipun gejala positif seperti halusinasi dan waham merupakan indikator penting dari penyakit ini. Gangguan fungsi kognitif merupakan gambaran utama dan relevan pada penderita skizofrenia. Fungsi kognitif ini merupakan indikasi penting terhadap hasil terapi dan fungsi keseharian penderita skizofrenia (Keefe \& Fenton, 2007). Medalia dan Choi (2009) menyebutkan bahwa kurang lebih 70-80\% penderita skizofrenia mengalami penurunan kognitif jika dibandingkan dengan populasi normal dan hampir $100 \%$ penderita skizofrenia mengalami penurunan kognitif jika dibandingkan dengan keadaan kognitif premorbid. Meskipun terdapat pengecualian bahwa gangguan memori kerja berhubungan dengan derajad keparahan gejala positif, secara keseluruhan kemampuan neurokognitif tidak berhubungan dengan keparahan gejala skizofrenia (Keefe \& Harvey, 2012). Proyek Measurement and Treatment Research to Improve Cognition in Schizophrenia (MATRICS) menghasilkan suatu kesepakatan, ada tujuh ranah penting yang berperan dalam fungsi kognitif skizofrenia yaitu memori kerja, atensi, kecepatan pemrosesan, pembelajaran dan memori verbal, pembelajaran dan memori visual, pertimbangan dan pemecahan masalah, kognisi sosial.

Penelitian-penelitian mengenai peran penting kognitif terhadap kemampuan fungsi sehari-hari menunjukkan hasil yang konsisten. Santosh, Roy \& Kundu (2013) menyebutkan bahwa memori kerja verbal, kecepatan psikomotor, atensi, fungsi eksekutif, dan kemampuan verbal berkorelasi secara signifikan dengan fungsi sosial pasien skizofrenia yang meliputi kemampuan rawat diri, okupasi, interaksi sosial, dan peran dalam keluarga. Penelitian mengenai peran kognitif terhadap kemampuan fungsi sosial penderita skizofrenia di Rumah Sakit Jiwa A dilakukan oleh (Ardiningrum, 2015) dan hasil penelitian tersebut menunjukkan korelasi antara semua ranah kognitif 
dengan kemampuan fungsi sosial pasien skizofrenia $\quad(p<0,05)$. Skor keparahan kognitif secara global mempunyai kekuatan korelasi yang kuat dengan kemampuan fungsi sosial.

Penanganan skizofrenia saat ini masih menitikberatkan pada pengendalian gejala dan cenderung mengesampingkan aspek kognitif (Keefe \& Fenton, 2007). Jika dibandingkan gejala psikotik, defisit kognitif dapat lebih memprediksi kemampuan fungsi sosial penderita skizofrenia (Keefe \& Fenton, 2007). Pemberian obat antipsikotika dapat mengurangi gejala psikotik pada sebagian besar penderita skizofrenia namun tidak banyak membantu pemulihan fungsi sosial (Green \& Harvey, 2014). Salah satu bentuk rehabilitasi kognitif adalah terapi remediasi kognitif.

Remediasi kognitif untuk skizofrenia menurut The Cognitive Remediation Experts Workshop tahun 2010, di Florence Italia, adalah suatu intervensi berbasis latihan perilaku yang bertujuan untuk memperbaiki proses kognitif (meliputi atensi, memori, fungsi eksekutif, kognisi sosial dan metakognisi) yang bersifat umum dan dapat bertahan lama (Wykes, Huddy, Cellard, McGurk,\& Czobo, 2011). Perkembangan remediasi kognitif didorong oleh banyaknya penelitian mengenai pentingnya faktor kognitif terhadap fungsi sosial, peran kognitif terhadap outcome rehabilitasi dan keluhan dari penderita skizofrenia yang mengalami gangguan fungsi kehidupan sehari-hari akibat penurunan fungsi kognitif (Wykes et al., 2011).

Remediasi kognitif merupakan metode untuk membantu seorang penderita skizofrenia untuk meningkatkan kemampuan kognitifnya sehingga dapat mencapai pemulihan fungsional baik dalam pekerjaan, akademik maupun kehidupan sehari-hari (Eack, 2012). Pendekatan praktis dari remediasi kognitif pada penderita skizofrenia dapat berupa berbagai macam bentuk latihan yang bertujuan untuk menentukan ranah kognitif yang menjadi target tumbuhnya neuroplastisitas otak (Eack, 2012). Terapi remediasi kognitif dianggap sebagai metode terapi yang lebih aman, sederhana dan tidak memerlukan biaya mahal dibandingkan dengan terapi farmakologi (Keefe \& Harvey, 2012).

Penelitian meta analisis menunjukkan bahwa remediasi kognitif dapat memperbaiki kinerja kognitif dengan effect size sedang (0.41), fungsi psikososial dengan effect size yang sedikit lebih rendah (0.35) dan perbaikan gejala dengan effect size yang kecil $(0,28)$ (McGurk, Twamley, Sitzer, McHugo \& Mueser, 2007). Perbaikan fungsi kognitif tersebut tidak tergantung pada model pendekatan latihan dan durasi latihan, namun lebih pada intensitas latihan (Wykes et al., 2011). Pengaruh remediasi kognitif lebih bermakna jika dikombinasikan dengan terapi rehabilitasi lain dibandingkan hanya menggunakan terapi remediasi kognitif saja (McGurk et al., 2007). Remediasi kognitif akan sangat bermanfaat jika dilakukan sejak awal gejala skizofrenia muncul atau diberikan terhadap individu berisiko menderita skizofrenia. Remediasi kognitif perlu dipertimbangkan sebagai upaya pencegahan timbulnya onset skizofrenia pada individu yang berisiko tinggi mengalami skizofrenia (Barlati, Deste, De Peri, Ariu \& Vita, 2013). Remediasi perlu dilakukan terutama pada fungsi kognitif dasar yang meliputi sensori, persepsi dan atensi. Perbaikan pada fungsi kognitif dasar akan mempermudah perbaikan pada fungsi kognitif yang lebih tinggi yaitu memori dan pengambilan keputusan (Posner \& Patterson, 1990).

Terapi remediasi kognitif dalam penelitian ini merupakan satu paket latihan standar yang diadaptasi dari 
modul Pontes et al. (2013). Latihan diberikan dalam bentuk tugas individu, dilakukan dalam satu kelas sehingga dapat dibimbing oleh 1-2 orang instruktur saja. Remediasi kognitif dilakukan dalam setting rawat inap dalam 12 kali pertemuan dengan intensitas empat kali seminggu, mengingat hari rawat inap yang relatif singkat yaitu berkisar 3-4 minggu. Model pendekatan dalam remediasi kognitif ini adalah latihan berulang-ulang dan latihan strategi. Materi remediasi menekankan pada ranah atensi dan memori yang merupakan ranah kognitif dasar dengan menggunakan materi yang mudah didapat dan relatif murah, berupa potongan berita koran, rekaman lagu dan berita, daftar belanja, kartu bergambar dan cerita pendek. Pemilihan bentuk remediasi semacam ini dianggap tepat untuk situasi rawat inap di RSJ A di Yogyakarta. Program remediasi kognitif efektif dalam memperbaiki fungsi kognitif pada penderita skizofrenia.

\section{Metode}

\section{Subjek penelitian}

Jumlah subyek penelitian ditetapkan sebanyak 14 orang dan pemilihan subyek dilakukan secara purposive sampling, yaitu berdasarkan kriteria yang telah ditetapkan. Subyek penelitian akan dibagi ke dalam kelompok perlakuan dan kelompok kontrol. Subyek penelitian adalah penderita gangguan jiwa berat dengan diagnosis skizofrenia (F 20.) yang sedang menjalani rawat inap di RSJ A di Yogyakarta yang memenuhi kriteria sebagai berikut : 1). Penderita skizofrenia (F20.) 2). Mengalami gangguan kognitif tingkat ringan-sedang. 3). Laki laki. 4). Berusia $20-45$ tahun 5). Menderita skizofrenia $>2$ tahun.6). Subyek sudah dinyatakan stabil oleh psikiater (nilai PANSS EC < 20) 7). Total skor gejala negatif tidak ada - sedang (rentang 7 - 28 menurut skala negatif dari PANSS). 8). Berpendidikan minimal SMP. 9). Onset penyakit didapatkan > usia 18 tahun.10). Tidak sedang menjalani atau mengikuti terapi psikologis lainnya. 11). Dapat berbahasa Indonesia dan bersedia menjadi subjek penelitian

Kriteria eksklusi subyek apabila : 1). Subyek mengalami gangguan mental organik (epilepsi, trauma kepala) 2). Pernah mendapatkan terapi kejang listrik 3). Mengalami ketergantungan terhadap zat kecuali tembakau 4). Mengalami gangguan penglihatan dan pendengaran 5). Mengalami kekambuhan saat mengikuti terapi

\section{Instrumen}

Pertama, Skala Negative Symptom dari Positive and Negative Symptom Scale (PANSS). Skala ini merupakan penilaian gejala negatif dari skizofrenia yang meliputi: afek tumpul, penarikan emosional, kemiskinan rapport, penarikan diri dari hubungan sosial secara pasif, kesulitan dalam pemikiran abstrak dan kurangnya spontanitas dan arus percakapan. Skala PANSS digunakan untuk melakukan skrining terhadap subyek.

Kedua, skala Cognitive Assasment Interview (CAI). Skala CAI merupakan suatu instrumen pengukuran berdasarkan wawancara terhadap subyek, informan dan penilaian dari klinisi. Penilaian CAI terdiri dari 10 aitem pertanyaan yang meliputi ranah atensi, memori kerja, kecepatan pemrosesan, pertimbangan dan pemecahan masalah, pembelajaran dan memori verbal, pembelajaran dan memori visual, dan kognisi sosial. Setiap ranah dinilai dengan skala 1 sampai 7 yaitu $1=$ Normal, tanpa gangguan kognitif; $2=$ minimal / ambang batas gangguan; $3=$ gangguan ringan; 4 = gangguan sedang; 5 = gangguan nyata; $6=$ gangguan berat; $7=$ 
gangguan paling ekstrem dan dengan tetap mencantumkan skor komposit keparahan global gangguan kognitif. CAI telah diadaptasi dan divalidasi oleh (Ardiningrum, 2015) dengan hasil uji reliabilitas konsistensi internal instrumen CAI didapatkan nilai Cronbach's alpha 0,85, reliabilitas inter-rater yang dinilai dengan koefisien Kappa (K) dinilai baik karena koefisien Kappa pada seluruh item dan skor total mendekati $1(\geq 0,70)$.

Ketiga, lembar observasi merupakan data kualitatif yang diperoleh dari pengamatan terhadap subyek maupun wawancara kepada perawat bangsal. Lembar observasi berisi beberapa pertanyaan panduan yang menggambarkan kemampuan fungsi kognitif selama mengikuti terapi dan kemampuan fungsi kognitif dalam konteks kehidupan sehari-hari.

Keempat, modul dalam penelitian ini diadaptasi dari modul Pontes (2013). Pertimbangan menggunakan modul ini adalah mudah dilaksanakan terhadap beberapa orang sekaligus dalam satu kelas, menggunakan peralatan yang murah dan mudah didapat dan dilakukan dalam durasi waktu yang relatif singkat karena menitikberatkan pada domain inti saja. Validasi modul melalui expert judgment. Dari hasil penilaian profesional judgement didapatkan nilai koefisien Aiken's V adalah berkisar 0,75 - 0,83 untuk masing-masing aitem.

\section{Intervensi}

Intervensi dilakukan dalam waktu 3 minggu dengan intensitas 4 kali pertemuan setiap minggu. Durasi waktu berlangsung 60-80 menit setiap kali pertemuan.

\section{Desain penelitian}

Jenis penelitian ini merupakan penelitian eksperimen kuasi dengan rancangan penelitian Untreated control group design with dependent pretest and posttest (Shadish, Cook \& Campbel, 2002). Subyek

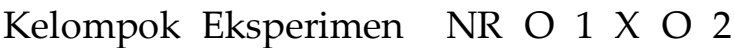

Kelompok Kontrol

NR O $1-\mathrm{O} 2$

ditempatkan tidak secara acak ke dalam dua kelompok yaitu kelompok perlakuan dan kelompok kontrol.

Desain penelitian dapat digambarkan sebagai berikut.

$$
\begin{array}{lll}
\text { Keterangan } & \mathrm{O} 1 & \text { : pre test } \\
& \mathrm{O} 2 & \text { : post test } \\
& \mathrm{X} & \text { : perlakuan } \\
& - & \text { : tanpa perlakuan }
\end{array}
$$

Analisis data

Analisis data kuantitatif menggunakan analisis nonparametrik dengan Mann Whitney $U$ test dan Wilcoxon sign rank testmelalui bantuan program SPSS versi 21.00 for windows.Pemilihan uji nonparametrik ini dengan pertimbangan bahwa jumlah subyek kecil sehingga kemungkinan data tidak terdistribusi secara normal. Analisis data deskriptif sebagai sumber data sekunder dilakukan dengan cara mengumpulkan dan mengorganisir data berdasarkan tema, dan melihat dinamika hubungan sebab akibat antar tema.

\section{Hasil}

Analisa data kelompok pada fungsi kognitif global 


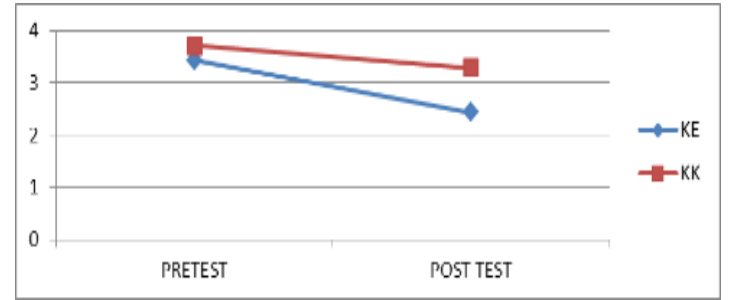

Ket. KE : kelompok eksperimen; KK: kelompok kontrol Gambar 1.

Grafik Skor Rerata Kelompok Eksperimen dan Kelompok Kontrol Berdasar CAI

Grafik pada gambar 1 menunjukkan bahwa terdapat penurunan rerata defisit kognitif antara pre test dan post test baik pada kelompok kontrol dan eksperimen. Penurunan defisit kognitif pada kelompok eksperimen lebih banyak dibanding kelompok kontrol. Uji Mann Whitney $U$ dilakukan untuk melihat perbedaan skor pre test pada kelompok eksperimen dan kontrol. Didapatkan nilai Z sebesar -0,680 dan nilai signifikansi sebesar 0,496 $(p>0,05)$. Dengan demikian tidak ada perbedaan defisit kognitif antara kelompok eksperimen dengan kelompok kontrol yang berarti kedua kelompok berada pada kondisi yang sama dan setara.

Uji statistik Wilcoxon signed rank pada skor pre test dan post test pada kedua kelompok. Pada kelompok eksperimen didapatkan nilai $Z$ adalah 2,000 dengan signifikansi $0,046 \quad(p<0,05)$ sehingga terdapat perbedaan yang bermakna skor pre test dan post test pada kelompok eksperimen. Uji Wilcoxon signed rank pada kelompok kontrol didapatkan nilai $Z$ sebesar $-1,732$ dan nilai signifikansi sebesar 0,083 ( $>00,05)$ dengan demikian tidak ada perubahan yang bermakna skor pre test dan skor post test pada kelompok kontrol. Nilai post test kelompok eksperimen dibandingkan dengan kelompok kontrol melalui uji Mann Whitney $U$ dan didapatkan nilai z sebesar 1,672 dan nilai signifikansi sebesar 0,094 $(p>0,05)$ sehingga tidak ada perbedaan yang bermakna pada skor post test antara kelompok eksperimen dan kontrol. Kesimpulan yang dapat diambil adalah : remediasi kognitif tidak efektif dalam memperbaiki defisit kognitif pada penderita skizofrenia. Dengan demikian hipotesis penelitian ini tidak terbukti

Hasil analisa berdasarkan ranah kognitif Hasil rerata pre test dan post test pada

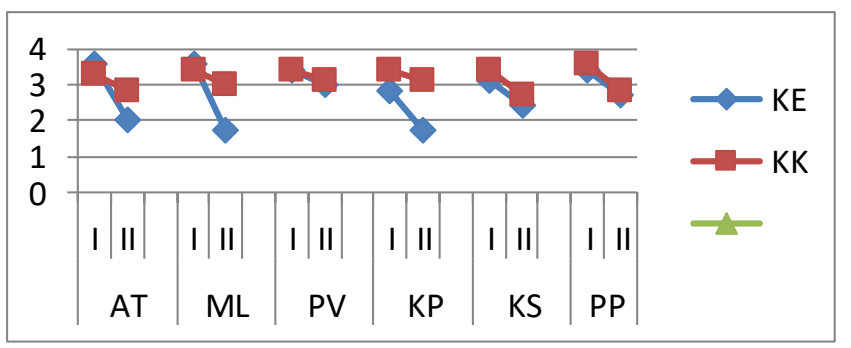

Ket. : AT : atensi, MK : memori kerja, PV : pembelajaran verbal, KS : Kognisi sosial, PP : Pertimbangan' KK : Kelompok Kontrol; KE : Kelompok eksperimen

Gambar 2.

Grafik Rerata Pre Test dan Post Test Kedua Kelompok Berdasarkan Ranah Kognitif

masing - masing ranah kognitif dapat dilihat pada gambar 2. Pada grafik terlihat penurunan skor rerata pre test - post test pada kelompok eksperimen yang lebih banyak dibandingkan kelompok kontrol yaitu atensi, memori kerja, kecepatan pemrosesan dan kognisi sosial. Uji nonparametric pada kedua kelompok dapat dilihat pada tabel 1 .

Tabel 1 dan 2 menunjukkan nilai signifikansi $\mathrm{p}<0,05$ pada ranah atensi, memori kerja dan kecepatan pemrosesan. Nilai effect size dapat dihitung berdasarkan rumus :

$$
r=\frac{Z}{\sqrt{N}} \quad \begin{array}{ll}
Z=\text { nilai } Z \\
N=\text { jumlah amatan }
\end{array}
$$

Kriteria effect size menurut Cohen adalah kecil $(<0,3)$, sedang $(0,3-0,5)$ dan besar $(>0,5)$ (Field, 2009). Hasil 
perhitungan effect size pada ranah atensi adalah 0,65, memori kerja sebesar 0,68 dan kecepatan pemrosesan sebesar 0,61. bosan, instruksi mudah dipahamioleh peserta, beberapa materi latihan sangat berhubungan dengan kegiatan sehari-hari,

Tabel 1.

Hasil Uji Mann Whitney Pre dan Post Test Berdasarkan Ranah Kognitif

\begin{tabular}{|c|c|c|c|c|c|c|c|}
\hline \multicolumn{2}{|c|}{$\begin{array}{l}\text { Uji Mann } \\
\text { Whitney }\end{array}$} & \multicolumn{3}{|c|}{ Pretest } & \multicolumn{3}{|c|}{ Post test } \\
\hline Ranah & Kel & $\begin{array}{c}\text { Rerata SKOR } \\
\text { CAI }\end{array}$ & z & $\mathrm{p}$ & $\begin{array}{c}\text { Rerata } \\
\text { SKOR CAI }\end{array}$ & $\mathrm{z}$ & $\mathrm{p}$ \\
\hline AT & $\begin{array}{l}\text { KE } \\
\text { KK }\end{array}$ & $\begin{array}{l}3,4286 \\
1,5000\end{array}$ & $-1,041$ & 0,298 & $\begin{array}{l}2,4286 \\
1,5000\end{array}$ & $-2,170$ & $0,030^{*}$ \\
\hline MK & $\begin{array}{l}\text { KE } \\
\text { KK }\end{array}$ & $\begin{array}{l}3,5000 \\
1,5000\end{array}$ & $-0,515$ & 0,606 & $\begin{array}{l}2,3571 \\
1,5000\end{array}$ & $-3,002$ & $0,003^{*}$ \\
\hline KP & $\begin{array}{l}\text { KE } \\
\text { KK }\end{array}$ & $\begin{array}{l}3,1429 \\
1,5000\end{array}$ & $-1,092$ & 0,275 & $\begin{array}{l}2,4286 \\
1,5000\end{array}$ & $-2,429$ & $0,015^{*}$ \\
\hline KS & $\begin{array}{l}\text { KE } \\
\text { KK }\end{array}$ & $\begin{array}{l}3,2857 \\
1,5000\end{array}$ & $-0,625$ & 0,532 & $\begin{array}{l}2,5714 \\
1,5000\end{array}$ & $-0,462$ & 0,644 \\
\hline
\end{tabular}

Keterangan : AT: atensi, MK: memori kerja, KP: kec. pemrosesan, KS: kognisi sosial,

KE : kelompok eksperimen, KK: kelompok kontrol, ${ }^{*}: \mathrm{p}<0,05$

Tabel 2.

Hasil Uji Wilcoxon Signed Rank Pre-Post Test Kedua Kelompok Berdasarkan Ranah Kognitif

Uji Wilcoxon signed KELOMPOK EKSPERIMEN KELOMPOK KONTROL

$$
\text { rank }
$$

\begin{tabular}{|c|c|c|c|c|c|c|c|}
\hline Ranah & & $\begin{array}{c}\text { Mean } \\
\text { SKOR CAI }\end{array}$ & z & $\mathrm{p}$ & Mean SKOR CAI & z & $\mathrm{p}$ \\
\hline \multirow[t]{2}{*}{ AT } & Pre test & 3,5714 & $-2,428$ & $0,015^{*}$ & 3,2857 & $-1,732$ & 0,083 \\
\hline & Post test & 2,0000 & & & 2,8571 & & \\
\hline \multirow[t]{2}{*}{ MK } & Pre test & 3,5714 & $-2,530$ & $0,011^{*}$ & $2,85713,0000$ & $-1,732$ & 0,083 \\
\hline & Post test & 1,7143 & & & & & \\
\hline \multirow[t]{2}{*}{$\mathrm{KP}$} & Pre test & 2,8571 & $-2,271$ & $0,023^{*}$ & 3,4286 & $-1,414$ & 0,157 \\
\hline & Post test & 1,7143 & & & 3,1429 & & \\
\hline \multirow[t]{2}{*}{ KS } & Pre test & 3,1429 & $-1,890$ & 0,059 & 3,4286 & $-1,633$ & 0,102 \\
\hline & Post test & 2,4286 & & & 2,8571 & & \\
\hline
\end{tabular}

Keterangan: AT: atensi, MK: memorikerja, KP:kec. pemrosesan, KS: kognisi sosial, ${ }^{*}$ signifikan p<0,05.

Kesimpulan yang dapat diambil adalah: remediasi kognitif efektif dalam memperbaiki fungsi kognitif pada penderita skizofrenia dengan effect size besar pada ranah atensi, memori kerja dan kecepatan pemrosesan yaitu sebesar 0,65 pada ranah atensi, 0,68 pada memori kerja dan 0,61 pada kecepatan pemrosesan.

Evaluasi juga dilakukan terhadap materi, proses remediasi dan kondisi peserta. Materi remediasi kognitif menggunakan bahan dan alat yang mudah diperoleh. menggunakan kartu bergambar yang menarik dan rekaman lagu yang menyenangkan membuat peserta tidak dan metode diskusi mendorong peserta berpartisipasi secara aktif. Salah satu kendala materi remediasi adalah topik mendengar angka dengan ketukandan topik mengingat daftar barang. Kedua aktivitas tersebut cenderung monoton sehingga membuat peserta cepat merasa bosan. Untuk mengatasi kebosanan tersebut maka terapis harus sering memberikan jeda waktu istirahat.

Evaluasi terhadap proses adalah secara umum peserta dapat mengikuti remediasi kognitif. Terapis dapat memberikan instruksi dengan jelas, mampu membawa peserta ke dalam 
suasana latihan yang menyenangkan, dapat mendorong peserta untuk aktif berpendapat dan memahami ketika peserta mulai merasa jenuh. Kendala dalam proses adalah ruangan yang berdekatan dengan bangsal perawatan sehingga sering diganggu oleh pasien lain yang ingin bergabung. Setting tempat duduk ruangan yang melingkar membuat salah satu peserta mengganggu peserta yang lain. Ko-terapis tidak dapat hadir setiap hari untuk membantu mengendalikan jalannya penelitian karena jadwal tugas di tempat lain. Selama penelitian ini ko-terapis hanya dapat hadir sebanyak 4 kali pertemuan.

Evaluasi terhadap peserta latihan secara umum semua peserta antusias mengikuti latihan dikarenakan tidak ada kegiatan di bangsal maupun di bagian rehabilitasi kerja. Kendala yang dihadapi adalah ada salah seorang peserta dengan afek meningkat dan cenderung gelisah sehingga mengganggu peserta lain. Adanya faktor stresor (yaitu keinginan pulang yang tinggi) memengaruhi konsentrasi peserta dalam melakukan tugas.

\section{Pembahasan}

Penelitian ini bertujuan untuk menilai efektivitas terapi remediasi kognitif terhadap perbaikan disfungsi kognitif pada penderita skizofrenia. Hasil penelitian menunjukkan terapi remediasi kognitif tidak efektif memperbaiki fungsi kognitif global sehingga hipotesis penelitian ini tidak terbukti. Meskipun demikian, terjadi perbaikan fungsi atensi, memori kerja dan kecepatan pemrosesan masing-masing dengan effect size besar (yaitu 0,68 pada ranah atensi, 0,65 pada ranah memori kerja dan 0,61 pada kecepatan pemrosesan).
Hasil penelitian ini sejalan dengan beberapa penelitian metaanalisis yang menunjukkan efektivitas remediasi kognitif terhadap perbaikan ranah-ranah kognitif dengan effect size kecil hingga besar. Penelitian oleh McGurk, et al. (2007) menunjukkan bahwa efektvitas remediasi kognitif dapat memperbaiki fungsi kognitif global dengan dengan effect size sedang (0.41), dengan effect size masingmasing ranah kognitif berkisar antara 0,09 (kecil) hingga 0,54 (sedang). Penelitian metaanalisis oleh Wykes et al. (2011) menunjukkan bahwa remediasi kognitif memperbaiki fungsi kognitif global dengan rata-rata effect size sedang (0.45) dan beberapa ranah kognitif menunjukkan efek yang signifikan dengan effect size berkisar antara 0.25 (kecil) hingga 0.65 (besar) (Wykes et al., 2011).

Penelitian ini juga menunjukkan bahwa remediasi kognitif memungkinkan untuk dilakukan dalam waktu relatif singkat. Ranah pembelajaran dan memori verbal tidak mengalami perbaikan yang signifikan karena perbaikan pada ranah kognitif tersebut membutuhkan waktu yang lebih panjang. McGurk et al. (2007) dalam penelitian meta analisisnya menyebutkan bahwa durasi waktu tidak memengaruhi pemulihan fungsi kognitif, kecuali pada ranah pembelajaran dan memori verbal.

Penelitian remediasi kognitif dalam rentang waktu singkat pernah dilakukan oleh Sartory, Zorn, Groetzinger, dan Windgassen (2005) yaitu remediasi kognitif dengan program komputer pada ranah memori verbal dengan durasi 15 jam dalam waktu 3 minggudapat memperbaiki memori verbal, kecepatan pemrosesan dan fungsi eksekutif dengan rata-rata effect size 0,78. Penelitian Hubacher et al. (2013) mengenai terapi remediasi kognitif sebanyak 16 sesi dalam waktu empat minggu menggunakan program komputer denganranah memori 
kerja efektif memperbaiki kemampuan memori kerja pada penderita skizofrenia kronis.

Remediasi kognitif pada penelitian ini tidak dapat memperbaiki fungsi kognitif secara global karena salah satu penentu keberhasilan terapi remediasi kognitif adalah kemampuan mentransfer ketrampilan yang sudah diperoleh ke dalam kehidupan sehari-hari (Eack, 2012). Secara keseluruhan, subyek dalam penelitian ini menunjukkan kemajuan pada saat mengikuti latihan di ruang kelas. Namun pada saat kembali ke bangsal subyek dengan gejala negatif dominan tidak menunjukkan perbaikan fungsi kognitif karena kurangnya stimulasi dari lingkungan. Subyek dengan gejala negatif dominan menunjukkan kemiskinan ide dan inisiatif sehingga membutuhkan lebih banyak dorongan dibanding pasien yang lebih aktif.

Pada umumnya penelitian remediasi kognitif dilakukan dalam setting rawat jalan. Penelitian mengenai remediasi kognitif oleh Pontes (2013) dilakukan pada pasien rawat jalan sehingga mereka mendapatkan kesempatan menerapkan keterampilan yang diperoleh sesuai konteks kehidupan sehari-hari. Remediasi pada penelitian ini dilakukan dalam setting rawat inap dan memiliki kelemahan yaitu pasien tidak dapat menerapkan kemampuan kognitifnya dalam kehidupan riil. Untuk menjembatani masalah tersebut maka terapis perlu memberikan tugas harian yang menghubungkan topik latihan dengan konteks kehidupan sehari-hari saat pasien kembali ke bangsal.

Model pendekatan pada remediasi kognitif ini menggunakan metode latihan yang berulang-ulang dan latihan strategi. Latihan strategi bertujuan untuk membantu pasien mengoptimalkan performa kognitif dengan cara menggeneralisir pemecahan masalah kognisi misalnya melakukan encoding informasi dalam berbagai cara (Eack, 2012). Dalam penelitian ini, latihan strategi dengan kategorisasi dan penelusuran sistematis mempermudah pasien dalam mengerjakan latihan. McGurk et al. (2007) menyebutkan bahwa remediasi kognitif yang memberikan latihan strategi memiliki efek yang lebih kuat pada perbaikan fungsi dibandingkan program yang hanya memfokuskan praktek berulang-ulang. Sedangkan menurut Wykes et al. (2011) kombinasi latihan strategi dan pengulangan tidak berbeda pengaruh secara signifikan jika dibandingkan pemberian latihan berulang-ulang tanpa latihan strategi.

Pada penelitian ini semua subyek memiliki motivasi mengikuti remediasi kognitif dan dapat mengikuti 12 sesi pertemuan hingga selesai. Subyek yang awalnya kurang berminat mengikuti latihan, menjadi bersemangat mengerjakan tugas dan mengalami kemajuan dalam latihan setelah memahami manfaat materi latihan terhadap pekerjaan mereka di rumah nanti. Medalia dan Choi (2005) menyebutkan bahwa motivasi pasien dan intensitas terapi memegang peranan penting dalam keberhasilan terapi. Motivasi juga dikaitkan dengan intensitas terapi yang merupakan salah satu faktor penting keberhasilan terapi. Penderita skizofrenia dengan motivasi yang besar mendapatkan intensitas terapi yang lebih banyak karena mereka mendatangi terapi secara teratur (Medalia \& Choi, 2005).

Proses remediasi kognitif dalam penelitian ini disesuaikan secara bertahap dengan kemampuan individual sehingga akan memotivasi mereka untuk mengikuti latihan-latihan berikutnya. Cara ini membuat pasien dapat makin terampil, lebih percaya diri dengan kemampuannya dan dapat lebih mandiri dalam mengerjakan latihan. Saat kemampuannya meningkat ritme latihan dapat dinaikkan 
secara bertahap. Wykes dan Spaulding (2011) menyebutkan bahwa pasien yang merasa dirinya mampu melakukan tugastugas yang diberikan akan meningkat rasa harga dirinya dan memungkinkan menerapkan serangkaian latihan tersebut dalam kehidupan sehari-hari.

Peran terapis sangat penting dalam meningkatkan keberhasilan program remediasi kognitif. Pada penelitian ini, terapis cukup peka terhadap beberapa perubahan yang terjadi dan dapat segera melakukan penanganan. Terapis dalam penelitian ini mampu menjalin komunikasi yang baik dengan pasien, dapat memotivasi pasien dan membawa proses terapi ke dalam suasana yang menyenangkan. Menurut Medalia dan Richardson (2005) keterampilan terapis ini dapat memengaruhi intensitas dan kehadiran pasien dalam terapi dan meningkatkan keberhasilan. Sedangkan menurut Wykes dan Spaulding (2011) terapis berperan dalam menanamkan harapan, meningkatkan motivasi atau karena keahlian khusus mereka (misalnya memilih tingkat dan jenis perangkat lunak komputer untuk peserta pelatihan). Kehadiran terapis dapat membawa kemungkinan hubungan positif antara terapis dan peserta.

Kondisi premorbid dapat memengaruhi keberhasilan terapi yaitu faktor pekerjaan dan tingkat pendidikan. Berdasarkan pengamatan, subyek yang mengalami pemulihan lebih baik adalah mereka yang memiliki aktivitas rutin di rumah atau pekerjaan tetap. Faktor tingkat pendidikan juga memengaruhi pemulihan fungsi kognitif. Subyek yang menunjukkan kemajuan yang lebih baik memiliki pendidikan yang lebih tinggi dibandingkan subyek yang lain. Penelitian oleh Srinivasan, Thara, dan Tirupati (2005) menyebutkan bahwa pendidikan yang rendah berhubungan dengan rendahnya kemampuan kognitif pada skizofrenia.
Lama menjalani pendidikan akademis formal merefleksikan fungsi premorbid yang baik, tingkat intelektual dan keterampilan memproses informasi yang lebih tinggi sebelumnya (Srinivasan et al., 2005).

Derajad defisit kognitif akan memengaruhi hasil remediasi kognitif. Pada penelitian ini subyek yang mengalami gangguan kognitif sedang membutuhkan waktu yang lebih lama untuk mengerjakan tugasnya dibandingkan subyek dengan defisit kognitif ringan atau minimal. Subyek dengan derajad kognitif yang lebih rendah mengalami kesulitan yang lebih besar dalam mempelajari tugas - tugasnya. Medalia dan Choi (2005) menyebutkan bahwa defisit kognitif yang lebih besar berhubungan dengan rasa frustrasi dalam mengerjakan tugas dan dapat menurunkan motivasi.

Faktor gejala disorganisasi dan gejala negatif dapat memengaruhi kemampuan pasien dalam mengerjakan latihan. Pada penelitian ini, didapatkan dua orang subyek dengan gejala disorganisasi menonjol, berupagerakangerakan repetitif yang tidak bertujuan dan tought disorder (perservasi pikiran) dan salah satu pasien dengan gejala negatif dominan. Gejala disorganisasi tersebut mengganggu pasien dalam berkomunikasi dan mengikuti proses terapi. Salah satu subyek dengan gejala negatif yang dominan juga mengalami kesulitan mengikuti proses terapi. Menurut Srinivasan et al. (2005) gejala negatif atau defisit perilaku abnormal berupa afek yang tumpul, gerak psikomotor lambat dan kemiskinan ide akan memengaruhi kemampuan kognitif.

Remediasi kognitif pada penelitian ini tidak diintegrasikan dengan layanan rehabilitasi kerja oleh karena kendala teknis. Kondisi tersebut dapat menjadi salah satu faktor yang memengaruhi hasil 
terapi. Beberapa bukti penelitian menunjukkan bahwa gabungan remediasi kognitif dan program rehabilitasi lain akan memberikan manfaat yang lebih banyak pada penderita skizofrenia. Salah satu contohnya adalah penelitian oleh McGurk et al. (2007) mengkombinasikan remediasi kognitif berbasis komputer dengan program dukungan pekerjaan mampu meningkatkan kompetensi penderita skizofrenia dalam memperoleh pekerjaan hingga tiga bulan setelah terapi selesai. Program Cognitive Enhancement Therapy (CET) merupakan integrasi program neurokognitif berbasis komputer dengan program kognisi sosial berbasis kelompok dan dapat memperbaiki fungsi neurokognisi dan kognisi sosial hingga 24 bulan setelah terapi (Hogarty et al., 2004).

Proses belajar sangat dipengaruhi oleh neuromodulator di otak. Beberapa obat antipsikotik bersifat menekan fungsi kognitif. Obat-obat antikolinergik, antidopaminergik, noradrenergik dan serotonergik dapat memengaruhi perbaikan neurokognitif (Vinogradov, 2012). Semua pasien dalam kelompok eksperimen maupun kontrol mendapatkan obat antikolinergik yang memengaruhi kemampuan atensi dan memori. Meskipun dosis dan jenis terapi yang didapatkan hampir sama, respon setiap pasien dapat berbeda-beda. Salah satu faktor pembeda respon terapi adalah faktor genetik yaitu Catechol-Omethyltransferase (COMT) rs4680 polymorphism yang berperan dalam modulasi dopamin (Bosia et al., 2014). Terdapat interaksi yang signifikan antara pemberian antipsikotik dan COMT polymorphism terhadap perbaikan kognitif dan respon terhadap terapi remediasi (Bosia et al., 2014).

Remediasi kognitif pada ranah kognitif tertentu dapat mendorong perbaikan pada ranah kognitif lain yang tidak menjadi fokus terapi. Pada penelitian ini, pasien-pasien yang mengalami perbaikan atensi, juga menunjukkan perbaikan pada ranah yang lain yaitu memori kerja dan kecepatan pemrosesan. Sejalan dengan hal tersebut Lindenmayer et al. (2012) melakukan remediasi pada neurokognisi dan persepsi emosi dan dapat memperbaiki aspek kognisi sosial lain yang lebih luas yaitu pengenalan emosi, membedakan emosi, fungsi sosial dan perbaikan pada neurokognisi. Penelitian oleh Penades et al. (2010) menyebutkan adanya perbaikan fungsi sehari-hari dan perbaikan fungsi kognisi sosial setelah remediasi kognitif pada ranah fungsi eksekutif saja. Penelitianpenelitian tersebut menunjukkan potensi efek pembelajaran, sehingga penderita skizofrenia dengan disfungsi kognitif masih dapat memetik manfaat dari remediasi kognitif terutama untuk memperbaiki fungsi kognitif dasar. Remediasi kognitif sebaiknya dipresentasikan dalam kerangka tujuan individual dan setiap program memiliki tautan yang jelas dengan tujuan tersebut.

\section{Kesimpulan}

Program remediasi kognitif pada penderita skizofrenia di bangsal rawat inap tidak efektif memperbaiki fungsi kognitif global. Remediasi kognitif efektif memperbaiki ranah atensi, memori kerja dan kecepatan pemrosesan dengan effect size besar yaitu 0,68 pada ranah atensi, 0,65 pada ranah memori kerja dan 0,61 pada kecepatan pemrosesan.

\section{Saran}

Kondisi ruang kelas dan setting tempat duduk sangat berpengaruh terhadap proses remediasi, sehingga penelitian berikutnya diharapkan dapat memperhatikan kondisi tersebut. 


\section{Kepustakaan}

American Psychiatric Association (APA). (2013). Diagnostic and statistic manual of mental disorder. (5th. ed.). Washington DC: American Psychiatric Publishing.

Ardiningrum, W. (2015). Korelasi antara domain kognitif dengan kemampuan fungsi sosial pasien skizofrenia di RSJ Grhasia. Tesis tidak dipublikasi. Universitas Gadjah Mada, Yogyakarta.

Barder, H. E., Sundet, K., Rund, B. R., Evensen, J., Haahr, U., Hegelstad, W. V., \& Friis, S. (2013). Neuro cognitive development in first episode psychosis 5 years follow-up: Associations between illness severity and cognitive course. Schizophrenia Research, 149(1-3), 63-9. doi: 10.1016 /j.schres.2013.06.016.

Barlati, S., Deste, G., DePeri, L., Ariu, C., \& Vita, A. (2013). Cognitive remediation in schizophrenia: Current status and future perspectives. Schizophrenia Research and Treatment. Italy: Hindawi Publishing Corporation. doi: 10.1155/2013/156084.

Bosia, M., Zanoletti, A., Spangaro, M., Buonocore, M., Bechi, M., Cocchi, F., Pirovano, A., \& Lorenzi, C. (2014). Factors affecting cognitive remediation response in schizophrenia: The role of COMT gene and antipsychotic treatment. Psychiatry Research, 217, 9-14.

Chong, H. Y., Teoh, S. L., Wu, D. B., Kotirum, S., Chiou, C. F., \& Chaiyakunapruk, N. (2016). Global economic burden of schizophrenia: a systematic review. Neuropsychiatry Disease Treatment, 16(12), 357-373. doi: 10.2147/NDT.S96649.

Eack, S. M. (2012). Cognitive remediation: A new generation of psychosocial interventions for people with schizophrenia. Social Work. 57(3): 235-246.

Field, A. ( 2009). Discovering statistics using spss. 3rd.Ed. London: Sage Publications Ltd.

Green, M. F., \& Harvey, P. D. (2014). Cognition in schizophrenia, past, present and future. Schizophrenia Research Cognition,1(1), Ie1-e9. doi: 10.1016/j.scog.2014.02.001

Harvey, P.D., \& Strassnig, M. (2012). Predicting the severity of everyday functional disability in people with schizophrenia: cognitive deficits, functional capacity, symptoms, and health status. World Psychiatry, 11(2), 73-79.

Hogarty, G. E., Flesher, S., Ulrich, R., Carter, M., Greenwald, D., Pogue-Geile, M., ... Zoretich, R. (2004). Cognitive enhancement therapy for schizophrenia: Effects of a 2-year randomized trial on cognition and behavior, frontiers in Psychiatry, 61(9), 866-876. doi:10.1001/archpsyc.61.9.866

Hubacher, M., Weiland, M., Calabrese, P., Stoppe, G., Stocklin, M., Barnicol, D. F., Opwis, K \&Penner, I. K. (2013). Research article, working memory training in patients with chronic schizophrenia: A pilot study. Psychiatry Journal, 8, 1-9. doi: 10.1155/2013/154867

Keefe, R. S., \& Fenton, W. S. (2007). How should $D S M-V$ criteria for schizophrenia include cognitive impairment?. Schizophrenia Bulletin, 33(4), 12-920. doi: 10.1093/ schbul/ sbm046

Keefe, R. S. E., \& Harvey, P. D. (2012). Cognitive impairment in schizophrenia. In: Geyer, M.A., \& Gross,G. (eds). Novel Antischizophrenia treatment, handbook of experimental pharmacology. Berlin 
Heidelberg: Springer-Verlag, pp. 1137.

Kementrian Kesehatan RI (Kemenkes RI). (2013). Riset Kesehatan Dasar. Retrieved from www.depkes.go.id/resources/downl oad/general/Hasil\%20Riskesdas $\% 202$ 013.pdf

Lindenmayer, J. P., McGurk, S. R., Khan, A., Kaushik, S., Thanju, A., Hoffman, L., ... \& Herrmann, E. Improving social cognition in schizophrenia: A pilot intervention combining computerized social cognition training with cognitive remediation. Schizophrenia Bulletin, 39(3), 507-17. doi: 10.1093/schbul/sbs120.

McGrath, J., Saha, S., Chant, D., \& Welham, J. (2008). Schizophrenia: a concise overview of incidence, prevalence, and mortality. Epidemiologic review, 30, 67 - 76. oi: 10.1093/epirev/mxn001

McGurk, S. R., Mueser, K. T., Pascaris, A., Feldman, K., \& Wolfe, R. (2007). Cognitive training and supported employment for persons with severe mental illness: one year results from a randomized controlled trial. Schizophrenia Bulletin, 31(4), 898-909.

McGurk, S. R., Twamley, E. W., Sitzer, D. I., McHugo, G. J., \& Mueser, K. T. (2007). A meta-analysis of cognitive remediation in schizophrenia. American Journal of Psychiatry, 164(12), 1791-1802.

Medalia, A., \& Choi, J. (2005). Factors associated with a positive response to cognitive remediation in a community psychiatric sample. Psychiatry Service, 56(5), 602-604.

Medalia, A., \& Choi, J. (2009). Cognitive Remediation in Schizophrenia. Neuropsychology Review, 19, 353 - 364.

Medalia, A., \& Richardson. (2005). What predict a good response to cognitive remediation intervention?.

Schizophrenia Bulletin, 31(4), 942 -953.

Penades, R., Catalán, R., Puig, O., Masana,

G., Pujol, N., Navarro, V., ...\& Gastó,

C. (2010). Executive function needs to be targeted to improve sosial functioning with cognitive remediation therapy (CRT) in schizophrenia. Psychiatry Research,177(1-2), 41-45. doi: 10.1016/j.psychres.2009.01.032.

Pontes, L.M., Martins, C.B., Napolitano, I.C., Fonseca, J.R., Oliveira, G.M., Iso, S.M.K., ... Elkis, H. (2013). Clinical study, cognitive training for schizophrenia in developing countries: a pilot trial in Brazil in Schizophrenia research and treatment. Brazil : Hindawi Publishing Corporation.

Posner \& Peterson. (1990). The attention system of the human brain. Annual Review Neuroscience, 13, 25-42.

Shadish, W. R., Cook, T. D., \& Campbell, D. T. (2002). Experimental and quasiexperimental designs for generalized causal inference. (2nd.Ed). Michigan: Houghton Mifflin.

Santosh, S., Roy, D. D.,\& Kundu, P. S. (2013). Psychopathology, cognitive function, and sosial functioning of patients with schizophrenia. East Asian Arch Psychiatry, 23(2), 65-70.

Sartory, G., Zorn, C., Groetzinger, G., \& Windgassen, K. (2005). Computerized cognitive rehabilitation improves verbal learning and processing speed in schizophrenia. Schizophrenia Research, 75(2-3), 219-223.

Srinivasan, L., Thara, R., \& Tirupati, S. N. (2005). Cognitive dysfunction and associated factors in patients with crhonic schizophrenia. Indian Journal of Psychiatry, 47(3), 139-143. doi: 10.4103/0019-5545.55936. 
Vinogradov, S., Fisher, M., \& Sidani, E. V. (2012). Cognitive training for impaired neural systems in neuropsychiatric illness. Neuropsychopharmacology Review, 37(1), 43-76. doi: 10.1038/ npp. 2011.251.

Wykes, T., Huddy, V., Cellard, C., McGurk, S. R., \& Czobor, P. (2011). A meta-analysis of cognitive remediation for schizophrenia: methodology and effect sizes. American Journal Psychiatry, 168, 472-485.

Wykes, T., \& Spaulding, W. D. (2011). Thinking about the future cognitive remediation therapy-what works and could we do better? Schizophrenia Bulletin, 37(S2), S80S90. doi: 10.1093/schbul/sbr064. 